\title{
Effect of Nitrogen and Foliar Sprays of Cattle Urine on Growth, Yield and Nutrient Uptake by Maize (Fodder) Grown on Inceptisol
}

\author{
A. B. Jadhav*, A. M. Marbhal, G. D. Patil, A. C. Jadhav and S. T. Pachpute \\ Division of Soil Science and Agricultural Chemistry, \\ College of Agriculture, Pune (Maharashtra), India \\ *Corresponding author
}

A B S T R A C T

\begin{tabular}{|l|}
\hline K e y w o r d s \\
Maize, cattle urine, \\
N levels, growth \\
and yield
\end{tabular}

A pot culture experiment was conducted to assess the effect of nitrogen and foliar sprays of cattle urine on growth, yield and nutrient uptake by maize (fodder) grown on Inceptisol at the Division of Soil Science and Agricultural Chemistry and Division of Animal Husbandry and Dairy Science, College of Agriculture, Pune, during Kharif-2018. The experiment consisted of 12 treatment combinations based on three levels of recommended dose of nitrogen (@ 0,75 and $100 \%$ ) through urea and four levels of cattle urine foliar spray (@ $0,5,10$ and $15 \%$ ) taken at 25, 45 and 65 DAS replicated thrice in Factorial Completely Randomized Design. The results revealed that application of $75 \% \mathrm{~N}$ through urea recorded significantly higher plant height, number of functional leaves and leaf area at 30,50 and 70 DAS of fodder maize which was found to be at par with $100 \% \mathrm{~N}$ through urea. While cattle urine foliar sprays @ $10 \%$ taken at 25, 45 and 65 DAS was found superior for plant height, number of functional leaves and leaf area of fodder maize at 30, 50 and 70 DAS which was closely followed by $15 \%$ cattle urine foliar spray. Interaction effect between $\mathrm{N}$ fertilizers and foliar sprays of cattle urine was found non-significant but combine application of $75 \% \mathrm{~N}$ through urea along with three foliar sprays of $10 \%$ cattle urine was recorded numerically higher plant height, number of functional leaves and leaf area of fodder maize. Statistically at par green fodder yield of maize was recorded with the application of either $75 \% \mathrm{~N}(971.75$ $\left.\mathrm{g} \mathrm{pot}^{-1}\right)$ or $100 \% \mathrm{~N}\left(962.83 \mathrm{~g} \mathrm{pot}^{-1}\right)$ through urea or foliar sprays of cattle urine either @ $10 \%\left(889.11 \mathrm{~g} \mathrm{pot}^{-1}\right)$ or $^{-1}$ $15 \%\left(821.78 \mathrm{~g} \mathrm{pot}^{-1}\right)$. Significantly higher N $\left(3.54 \mathrm{~g} \mathrm{pot}^{-1}\right), \mathrm{P}\left(0.90 \mathrm{~g} \mathrm{pot}^{-1}\right)$ and $\mathrm{K}\left(4.84 \mathrm{~g} \mathrm{pot}^{-1}\right)$ uptake by fodder maize was reported with the application of $100 \% \mathrm{~N}$ through urea which was followed by $75 \% \mathrm{~N}$ for $\mathrm{N}(2.85 \mathrm{~g}$ $\left.\operatorname{pot}^{-1}\right), \mathrm{P}\left(0.76 \mathrm{~g} \mathrm{pot}^{-1}\right)$ and $\mathrm{K}\left(4.34 \mathrm{~g} \mathrm{pot}^{-1}\right)$. However, application of cattle urine foliar sprays @ $15 \%$ recorded significantly higher $\mathrm{N}\left(3.15 \mathrm{~g} \mathrm{pot}^{-1}\right)$ uptake by fodder maize which was closely followed by $10 \%\left(2.69 \mathrm{~g} \mathrm{pot}^{-1}\right)$. Higher P uptake by fodder maize was observed with $10 \%$ cattle urine foliar spray $\left(0.83 \mathrm{~g} \mathrm{pot}^{-1}\right)$ which was followed by $15 \%\left(0.75 \mathrm{~g} \mathrm{pot}^{-1}\right)$ however $10 \%$ cattle urine foliar sprays recorded significantly higher $\mathrm{K}(4.51 \mathrm{~g}$ pot $\left.^{-1}\right)$ uptake by fodder maize than rest of treatment.

\section{Introduction}

Maize is also known as corn and that was first grown by people of Central America. It is now the third most important cereal crop in the world and is called "Queen of cereals" because it has highest genetic potential among the cereals. Maize is one of the most versatile emerging crops having wider adaptability under varied agro-climatic conditions. It is cultivated as nearly $150 \mathrm{~m}$ ha in about 160 countries having wider diversity of soil, climate, biodiversity and management practices that contributes $3.6 \%$ in the global grain production. The United States of America (USA) is the largest producer of maize contributes nearly $35 \%$ of the total production in the world. 
India produces about $2 \%$ the world maize produce. Maize production in Maharashtra was 3.8 million tones that accounts for $15.17 \%$ of India's production in 2017. About $71 \%$ of maize in India is produced in the kharif season. Karnataka is the leading producer of maize followed by Madhya Pradesh, Tamil Nadu, Telengana, Uttar Pradesh and Rajasthan. India's corn productivity is about half the world's average (NCML report, 2017). The reasons for lower productivity are imbalanced and indiscriminate use of chemical fertilizers and limited us of organic manures which leads to deterioration of soil health and fertility. So integrated nutrient management is the most is the most appropriate and adoptable practice in which organic, inorganic and biofertilizers are used for enhancing crop production and productivity.

The integrated use if inorganic fertilizers with the liquid organic manures (cattle urine) can help to maintain optimum crop yield by maintaining fertility status of the soil. Cattle urin contains $95 \%$ water, $2.5 \%$ urea and $2.5 \%$ minerals, salts, hormones and enzymes. It also contains essential nutrients like nitrogen, phosphorus, potassium, calcium, magnesium, sulphur, uric acid, amino acids enzymes, cytokinins etc. (Bhadauria 2002). The use of cattle urine is known for long time in India. Cow urine has been described as a liquid with good nutrient value having capacity to supply essential nutrients to plants. It can be act as bio-fertilizer, bio-pesticides and rich source of macro, micro nutrients and has capacity to improve soil fertility. Use of cattle urine alone or in combination with chemical fertilizers can increase the productivity of soil crop.

Therefore, use of cow urine in agriculture has effective way to address multi-nutrient deficiencies in the soils of India and Maharashtra. The beneficial effect of cattle urine application has been reported on several crops such as Maize (Devakumar et al., 2014), Sweet corn (Pande et al., 2015), Mustard (Pradhan et al., 2016). In view of this, the present study entitled "effect of nitrogen and foliar sprays of cattle urine on growth, yield and nutrient uptake by maize (fodder) grown on Inceptisol".

\section{Materials and Methods}

Pot culture experiment was conducted to study the effect of nitrogen and foliar sprays of cattle urine on growth, yield and nutrient uptake by maize (fodder) grown on Inceptisol at the Division of Soil Science and Agricultural Chemistry and Animal Husbandry and Dairy Science, College of Agriculture, Pune, during Kharif-2018. There were 12 treatments consisting of three levels of nitrogen (@0,75 and $100 \mathrm{~kg} \mathrm{ha}^{-1}$ ) and four levels of cattle urine foliar sprays (@ 0,5,10, and $15 \%$ ) imposed to maize (fodder). The foliar sprays were taken at 25,45 and $65^{\text {th }}$ days after sowing. There were total 36 plastic pots of diameter $41 \mathrm{~cm}$ and height $38 \mathrm{~cm}$ were used to conduct the experiment. The pots were washed with water and then filled each with gravel at the bottom and $2 \mathrm{~mm} 30 \mathrm{~kg}$ sieved soil.

The experimental soil was characterized by black colour dominated by montmorillonite clay comes under the Typic Haplustept and well drained. The soil was moderately calcareous (free $\mathrm{CaCO}_{3}: 5.25 \%$ ) in nature with alkaline $\mathrm{pH}: 8.34$, EC: $0.13 \mathrm{~d} \mathrm{Sm}^{-1}$ and organic carbon: $0.66 \%$. The alkaline $\mathrm{KMnO}_{4}-$ $\mathrm{N}$, Olsen's $\mathrm{P}$ and $\mathrm{NH}_{4} \mathrm{OAC}-\mathrm{K}$ in the experimental soil was 200.70, 18 and 571.20 $\mathrm{kg} \mathrm{ha}{ }^{-1}$ respectively. The soil $\mathrm{KMnO}_{4}-\mathrm{N}$,

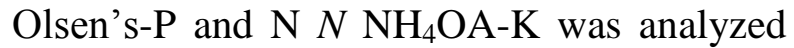
by methods given by Subbia and Asijia, 1956, Olsen et al., 1954 and Knudsen et al., 1982 respectively. The soil $\mathrm{CaCO}_{3}$ content was assessed by rapid titration method prescribed by Jackson, 1973. 
Further treatment wise required quantity of $\mathrm{N}$, $\mathrm{P}_{2} \mathrm{O}_{5}$ and $\mathrm{K}_{2} \mathrm{O}$ through urea, single super phosphate and muriate of potash were mixed thoroughly with soil. The nitrogen @ $50 \% \mathrm{~N}$ $+100 \% \mathrm{P} 2 \mathrm{O} 5+100 \% \mathrm{~K} 2 \mathrm{O}$ were mixed at the time of sowing as basal dose and remaining $50 \% \mathrm{~N}$ was applied at $30 \mathrm{DAS}$ of maize.

On the basis of recommended dose of nitrogen for maize (fodder) @ $100 \mathrm{~kg} \mathrm{ha}^{-1}$ three levels of nitrogen were formulated as 0 $\%, 75 \%$ and $100 \%$. In order under take foliar spray of cattle urine at 25, 45 and 65 DAS fresh urine was collected at each time in early morning. Water sprays at respective days were undertaken for $0 \%$ as control. The required volume of cattle urine for 5,10 and $15 \%$ concentration and sprayed at respective growth stage by using 2 lit capacity hand pump.(Table 1) Cattle urine was analyzed for nutrient composition before every spray by following standard method (Table 2). During foliar spray due care was taken by considering foliage of maize at respective growth stage. The truthful maize seed of variety African tall was procured from Division of Animal Husbandry and Dairy Science, College of Agriculture Pune. There were total six seed seeds sown equidistantly and four plants were maintained throughout experiment.

The maize plant height at respective growth stage was measured for four plants by using measuring scale. The height of the plant was measured from the base to the top. The number of fully opened functional leaves of four plants from each pot were counted and recorded. The length of fully opened functional leaf was measured from the base of leaf to the tip and width at middle portion for four plants. The leaf area $\left(\mathrm{cm}^{2}\right)$ was calculated by multiplying length of leaf $(\mathrm{cm})$ and width $(\mathrm{cm}) \times 0.75$ correction factor as given by Tanko and Hassan (2016). The four plants from each pot was harvested and immediately weighed in gram $\operatorname{pot}^{-1}$. The four maize plants from each pot were cut down at harvest and weighed fresh. The composite samples from each pot were air dried, oven dried and accordingly \% dry matter was calculated. Nitrogen, phosphorous and potassium were analyzed from composite sample of fodder maize. The nutrient concentration was analyzed by digesting composite fodder maize sample. The nutrient uptake was calculated by using dry matter and nutrient concentration and expressed in $\mathrm{g} \mathrm{pot}^{-1}$ for $\mathrm{N}, \mathrm{P}$ and $\mathrm{K}$.

\section{Results and Discussion}

\section{Plant height, number of functional leaves and leaf area}

Effect of $\mathrm{N}$ levels and foliar sprays of cattle urine taken at 25, 45 and 65 DAS were significantly influenced plant height, number of functional leaves and leaf area of maize (fodder) grown on Inceptisol (Table 3a, 3b and 3c). Application of $75 \%$ RDN recorded significantly higher plant height, number of functional leaves and leaf area measured at 30, 50 and 70 DAS. Significantly higher plant height at 30 DAS $(83.06 \mathrm{~cm}), 50$ DAS $(133.50 \mathrm{~cm})$ and 70 DAS $(170.92 \mathrm{~cm})$ reported with the application of $75 \% \mathrm{RDN}$ which was found statistically at par with $100 \%$ RDN. Foliar application of cattle urine @ 10\% reported significantly higher plant height of maize at 30 DAS $(80.06 \mathrm{~cm}), 50$ DAS $(130.56 \mathrm{~cm})$ and 70 DAS $(164.78 \mathrm{~cm})$ which was found on par with $15 \%$ foliar spray of cattle urine. While combine application of $\mathrm{N}$ fertilizers and foliar sprays of cattle urine reported non-significant results for plant height.

In case of number of functional leaves of maize, application of $75 \% \mathrm{~N}$ reported higher plant height at 30 (5.42), 50 (5.75) and 70 DAS (7.56) which was also found statistically 
on par with $100 \%$ RDN. Foliar spray of cattle urine@10\% reported significantly higher number of functional leaves at 30 (5.47), 50 (5.86) and 70 DAS (7.42) however this treatment was found on par with foliar spray @ 15\% application. But combine application of $\mathrm{N}$ fertilizers and cattle urine foliar sprays reported non-significant results for functional leaves.

Maize (fodder) leaf area was significantly higher with application of $75 \% \mathrm{~N}$ at 30 $\left(204.59 \mathrm{~cm}^{2}\right), 50\left(358.26 \mathrm{~cm}^{2}\right)$ and $70(482.73$ $\mathrm{cm}^{2}$ ) DAS which was found at par with $100 \%$ $\mathrm{N} \quad\left(203.14,314.06\right.$ and $\left.476.93 \mathrm{~cm}^{2}\right)$ respectively. Application of cattle urine foliar spray@10\% reported non-significant effect on leaf area at 30 DAS but it was significant at $50\left(365.89 \mathrm{~cm}^{2}\right)$ and $70\left(473.51 \mathrm{~cm}^{2}\right)$ DAS. Non-significant effect on maize leaf area was recorded with combine application of $\mathrm{N}$ fertilizers and foliar sprays of cattle urine.

It could be observed from the data that three foliar sprays of cattle urine @ 10\% taken at 25, 45 and 65 DAS was reported more or less equal effects as that of $75 \% \mathrm{~N}$ application on plant height, number of leaves and leaf area. Enhanced height of plant due to sprays of cattle urine might be due to nitrogen, phosphorous and potassium content with some growth stimulant hormones content in cattle urine (Choudhary et al., 2017). Application of cow urine on chickpea at the rate of $10 \%$ at flowering initiation and 15 days after flowering recorded higher plant height $(35.78 \mathrm{~cm})$, as compare to control. (Patil et al., 2012). Similarly Singh, et al., (2014) reported that the application of nitrogen @ $90 \mathrm{~kg} \mathrm{ha}{ }^{-1}$ with $60 \mathrm{~kg} \mathrm{ha}^{-1}$ potassium and phosphorus + cow urine was found to be the best treatment regarding growth of paddy.

These results are in conformity with the findings of Masti et al., 2003 where liquid cattle manure applied to soil did not affect the seed germination but resulted in a significant increase in plant height, number of green leaves and dry biomass of maize relative to control and was at par with that fertilizer treatment. Ravi kumar et al., (2012) also reported that plant height significantly higher with application of FYM (7.5 t/ha) + Rhizobium + PSB + Panchagavya spray (3\% at 30,60 and 75 DAS) as compared to other treatments except application of FYM (7.5 t/ha) + Rhizobium + PSB + Jeevamruta (equivalent to $25 \mathrm{~kg} \mathrm{~N} / \mathrm{ha}$ ) which were at par with each other.

\section{Green fodder yield}

The green fodder yield of maize was significantly influenced the application of $\mathrm{N}$ fertilizers and three foliar sprays of cattle urine taken at 25, 45 and 65 DAS. (Table 5)

Application of $75 \% \mathrm{~N}$ through urea recorded significantly higher green fodder yield of maize (971.75 $\mathrm{g} \mathrm{pot}^{-1}$ ) which was closely followed and statistically at par with $100 \% \mathrm{~N}$ (962.83 $\left.\mathrm{g} \mathrm{pot}^{-1}\right)$. Significantly higher green fodder yield of maize (889.11 $\mathrm{g} \mathrm{pot}^{-1}$ ) was recorded with $10 \%$ cattle urine three sprays which were followed and statistically on par with $15 \%$ cattle urine spray $\left(821.78 \mathrm{~g} \mathrm{pot}^{-1}\right)$. Application of water spray and $5 \%$ recorded lower green fodder yield of maize as (745.56 $\left.\mathrm{g} \mathrm{pot}^{-1}\right)$ and $\left(805.67 \mathrm{~g} \mathrm{pot}^{-1}\right)$ respectively.

The interaction effect between nitrogen levels and foliar sprays of cattle urine on maize green fodder yield was found non-significant. But numerically higher green fodder yield was recorded with combine application of 75 $\% \mathrm{~N}$ through urea along with three cattle urine sprays @ $10 \%$ (1061.33 g pot $\left.^{-1}\right)$. Higher green fodder yield with foliar sprays of cattle urine might be due to timely nutrient absorption from cattle urine sprays taken at different growth stages maize (fodder). 
Further this might be the cumulative effect of hormones, essential nutrients and enzymes present in cattle urine which increased growth rate and accumulation of photosynthetes. The increased growth and dry matter production of maize might be due to efficient absorption of $\mathrm{N}$ through cattle urine which ultimately resulted in higher yield. Further higher green fodder yield with foliar sprays of cattle urine might have beneficial effect on cell elongation, cell division, formation of nucleotide and co-enzymes in meristematic activity and also increased photosynthetic area which ultimately enhanced the green matter (Verma 1989). Higher plant height, number of functional leaves and leaf area leading to more photosynthetic area there by resulting in higher maize green biomass yield. These results are in conformity with the finding of Sathyamoorthi K.(1997) where higher leaf area and nutrient uptake might have contributed for higher green fodder yield by the application of liquid panchagavya and cattle urine spray.

Nutrient content in cattle urine like $\mathrm{N}, \mathrm{P}, \mathrm{K}$, $\mathrm{Ca}, \mathrm{Mg}, \mathrm{SO} 4$ and $\mathrm{Fe}$ along with animal hormones and enzymes might have played cumulative effect to enhance the photosynthesis rate there by increased green fodder yield of maize. Similar results were also reported by Rahman et al., (2008) for fodder maize. They concluded that application of $12 \mathrm{~kg}$ cattle slurry $10 \mathrm{~m}^{2}$ plot reported higher maize biomass yield (45 $\mathrm{t}$ ha $\left.{ }^{1}\right)$. These results are in corroboration with the findings of Meena and Bheemavat (2009) that cow urine combined with application of green manures and foliar application of panchagavya twice on the standing crop resulted in better growth and development of plants for increase green fodder yield of maize. Sandhukhan et al., (2018) concluded that application of $50 \%, 25 \%$ and $100 \%$ cow urine spray recorded $2.69 \%, 18.01 \%$ and $27.21 \%$ respectively higher grain yield of wheat. Sharma et al., (2016) also concluded that application of $\mathrm{N} @ 150 \mathrm{~kg} \mathrm{ha}^{-1}$ through urine recorded higher biological yield and curd yield of broccoli which was followed by application of $\mathrm{N} @ 50 \mathrm{~kg} \mathrm{ha}^{-1}$.Similar results were also quoted by Nelson et al., (2009), Singh, et al., (2014), Iqbal, et al., (2014).

\section{Nutrient uptake}

The data presented in tables (Table 5) indicated that nitrogen, phosphorous and potassium uptake by maize fodder grown in Inceptisol was significantly influenced by graded levels of $\mathrm{N}$ fertilizers and three cattle urine foliar sprays applied at 25, 45 and 65 DAS with four concentrations $(0,5,10$ and $15 \%)$.

Table.1 Quantity of cattle urine used for spraying

\begin{tabular}{|c|c|c|c|c|c|c|c|c|c|}
\hline \multirow{2}{*}{$\begin{array}{c}\text { Cattle } \\
\text { urine } \\
\%\end{array}$} & \multicolumn{2}{|c|}{$\begin{array}{l}\text { First Spray } \\
\left(25^{\text {th }} \text { DAS }\right)\end{array}$} & \multirow{2}{*}{$\begin{array}{c}\text { Total } \\
\text { volume of } \\
\text { spray } \\
(\mathrm{ml})\end{array}$} & \multicolumn{2}{|c|}{$\begin{array}{l}\text { Second Spray } \\
\left(45^{\text {th }} \text { DAS }\right)\end{array}$} & \multirow{2}{*}{$\begin{array}{c}\text { Total } \\
\text { volume } \\
\text { of } \\
\text { spray } \\
\text { (ml) }\end{array}$} & \multicolumn{2}{|c|}{$\begin{array}{l}\text { Third Spray } \\
\left(65^{\text {th }} \text { DAS }\right)\end{array}$} & \multirow{2}{*}{$\begin{array}{c}\text { Total } \\
\text { volume of } \\
\text { spray } \\
(\mathrm{ml})\end{array}$} \\
\hline & $\begin{array}{l}\text { Quantity of } \\
\text { cattle urine } \\
\text { (ml) }\end{array}$ & $\begin{array}{c}\text { Quantity } \\
\text { of water } \\
\quad(\mathrm{ml})\end{array}$ & & $\begin{array}{l}\text { Quantity } \\
\text { of cattle } \\
\text { urine } \\
\text { (ml) }\end{array}$ & $\begin{array}{l}\text { Quantity } \\
\text { of water } \\
(\mathrm{ml})\end{array}$ & & $\begin{array}{l}\text { Quantity } \\
\text { of cattle } \\
\text { urine (ml) }\end{array}$ & $\begin{array}{c}\text { Quantity } \\
\text { of water } \\
\text { (ml) }\end{array}$ & \\
\hline $\mathbf{0}$ & 0 & 1500 & 1500 & 0 & 2250 & 2250 & 0 & 3000 & 3000 \\
\hline 5 & 75 & 1425 & 1500 & 112.5 & 2137.5 & 2250 & 150 & 2850 & 3000 \\
\hline 10 & 150 & 1350 & 1500 & 225 & 2025 & 2250 & 300 & 2700 & 3000 \\
\hline 15 & 225 & 1275 & 1500 & 337.5 & 1912.5 & 2250 & 450 & 2550 & 3000 \\
\hline
\end{tabular}


Table.2 Cattle urine analysis

\begin{tabular}{|c|c|c|c|c|c|}
\hline $\begin{array}{l}\text { Sr. } \\
\text { No }\end{array}$ & Parameter & $\begin{array}{c}\text { Before } 1^{\text {st }} \\
\text { spray }\end{array}$ & $\begin{array}{c}\text { Before } 2^{\text {nd }} \\
\text { spray }\end{array}$ & $\begin{array}{c}\text { Before } 3^{\text {rd }} \\
\text { spray }\end{array}$ & Average \\
\hline 1 & pH & 7.09 & 8.05 & 7.30 & 7.63 \\
\hline 2 & $\mathrm{EC} \mathrm{dSm^{-1 }}$ & 16.71 & 18.65 & 20 & 18.45 \\
\hline 3 & OC \% & 1.67 & 1.56 & 2.19 & 1.81 \\
\hline 4 & $\mathbf{N} \%$ & 0.75 & 0.83 & 0.55 & 0.71 \\
\hline 5 & P \% & 0.052 & 0.08 & 0.084 & 0.048 \\
\hline 6 & K \% & 0.84 & 0.64 & 1.09 & 0.86 \\
\hline 7 & $\mathrm{Ca} \%$ & 0.02 & 0.010 & 0.012 & 0.014 \\
\hline 8 & $\mathrm{Mg} \%$ & 0.042 & 0.054 & 0.037 & 0.044 \\
\hline 9 & $\mathrm{SO}_{4} \%$ & 0.035 & 0.052 & 0.033 & 0.040 \\
\hline
\end{tabular}

Table.3 Effect of $\mathrm{N}$ fertilizers and foliar sprays of cattle urine on growth of maize (fodder) grown on Inceptisol

a) Plant height At $30^{\text {th }}$ DAS

\begin{tabular}{|c|c|c|c|c|c|}
\hline CUS & \multicolumn{4}{|c|}{ Plant height $(\mathbf{c m})$} & Mean \\
\hline RDN & $\mathbf{0} \%$ & $\mathbf{5 \%}$ & $\mathbf{1 0} \%$ & $\mathbf{1 5} \%$ & \\
\hline $\mathbf{0} \%$ & 68.33 & 69.67 & 71.50 & 70.50 & 70.00 \\
\hline $\mathbf{7 5} \%$ & 80.33 & 82.73 & 85.50 & 83.67 & 83.06 \\
\hline $\mathbf{1 0 0} \%$ & 82.00 & 82.33 & 83.17 & 82.83 & 82.58 \\
\hline Mean & 76.89 & 78.24 & 80.06 & 79.00 & \\
\hline
\end{tabular}

\begin{tabular}{|c|c|c|c|}
\hline & RDN & CUS & RDN $\times$ CUS \\
\hline S.E. \pm & 0.570 & 0.659 & 1.141 \\
\hline CD at 5\% & 1.675 & 1.934 & NS \\
\hline
\end{tabular}

$$
\text { At } 50^{\text {th }} \text { DAS }
$$

\begin{tabular}{|c|c|c|c|c|c|}
\hline CUS & \multicolumn{4}{|c|}{ Plant height $\mathbf{( c m )}$} & Mean \\
\hline RDN & $\mathbf{0 \%}$ & $\mathbf{5 \%}$ & $\mathbf{1 0} \%$ & $\mathbf{1 5} \%$ & \\
\hline $\mathbf{0} \%$ & 97 & 102.44 & 113.33 & 110.50 & 105.82 \\
\hline $\mathbf{7 5} \%$ & 119.83 & 135.33 & 142.00 & 136.83 & 133.50 \\
\hline $\mathbf{1 0 0} \%$ & 120.83 & 132.00 & 136.33 & 136.50 & 131.42 \\
\hline Mean & 112.55 & 123.26 & 130.56 & 127.94 & \\
\hline & RDN & & CUS & & RDN $\times$ CUS \\
\hline S.E. $\mathbf{\pm}$ & 0.912 & & 1.053 & & 1.824 \\
\hline CD at 5\% & 2.678 & & 3.092 & & NS \\
\hline
\end{tabular}




\section{At $70^{\text {th }} \mathrm{DAS}$}

\begin{tabular}{|c|c|c|c|c|c|}
\hline \multirow{2}{*}{$\begin{array}{l}\text { CUS } \\
\text { RDN }\end{array}$} & \multirow[b]{2}{*}{$0 \%$} & \multicolumn{2}{|c|}{ Plant height (cm) } & \multirow[b]{2}{*}{$15 \%$} & \multirow[t]{2}{*}{ Mean } \\
\hline & & $5 \%$ & $10 \%$ & & \\
\hline $0 \%$ & 127.17 & 133.00 & 136.17 & 134.33 & 132.67 \\
\hline $75 \%$ & 153.67 & 165.83 & 184.83 & 179.33 & 170.92 \\
\hline $100 \%$ & 155.83 & 172.17 & 173.33 & 174.33 & 168.92 \\
\hline \multirow[t]{2}{*}{ Mean } & 145.56 & 157.00 & 164.78 & 162.67 & \\
\hline & RDN & & CUS & & $\mathbf{R D N} \times \mathbf{C U S}$ \\
\hline S.E. \pm & 1.826 & & 2.108 & & 3.651 \\
\hline CD at $5 \%$ & 5.360 & & 6.189 & & NS \\
\hline
\end{tabular}

b) Number of functional leaves at 30 DAS

\begin{tabular}{|c|c|c|c|c|c|}
\hline \multirow{2}{*}{$\begin{array}{l}\text { CUS } \\
\text { RDN }\end{array}$} & \multicolumn{4}{|c|}{ Number of functional leaves } & \multirow[t]{2}{*}{ Mean } \\
\hline & $0 \%$ & $5 \%$ & $10 \%$ & $15 \%$ & \\
\hline $0 \%$ & 4.45 & 4.50 & 5.42 & 5.17 & 4.88 \\
\hline $75 \%$ & 4.83 & 5.42 & 5.75 & 5.67 & 5.42 \\
\hline $100 \%$ & 4.92 & 5.17 & 5.25 & 5.33 & 5.17 \\
\hline \multirow[t]{2}{*}{ Mean } & 4.73 & 5.03 & 5.47 & 5.39 & \\
\hline & RDN & & CUS & & RDN $\times$ CUS \\
\hline S.E. \pm & 0.121 & & 0.140 & & 0.242 \\
\hline CD at $5 \%$ & 0.356 & & 0.411 & & NS \\
\hline
\end{tabular}

\section{At 50 DAS}

\begin{tabular}{|c|c|c|c|c|c|}
\hline CUS & \multicolumn{3}{|c|}{ Number of functional leaves } & & \multirow[t]{2}{*}{ Mean } \\
\hline RDN & $0 \%$ & $5 \%$ & $10 \%$ & $15 \%$ & \\
\hline $0 \%$ & 4.75 & 5.08 & 5.50 & 5.25 & 5.15 \\
\hline $75 \%$ & 5.25 & 5.68 & 6.17 & 5.92 & 5.75 \\
\hline $100 \%$ & 5.17 & 5.75 & 5.92 & 5.92 & 5.69 \\
\hline \multirow[t]{2}{*}{ Mean } & 5.06 & 5.51 & 5.86 & 5.69 & \\
\hline & RDN & & CUS & & RDN $\times$ CUS \\
\hline S.E. \pm & 0.125 & & 0.145 & & 0.251 \\
\hline CD at $5 \%$ & 0.368 & & 0.425 & & NS \\
\hline
\end{tabular}

At 70 DAS

\begin{tabular}{|c|c|c|c|c|c|}
\hline RDN & $\mathbf{0} \%$ & $\mathbf{5 \%}$ & $\mathbf{1 0} \%$ & $\mathbf{1 5} \%$ & \\
\hline $\mathbf{0 \%}$ & 6.25 & 6.42 & 6.67 & 6.58 & 6.48 \\
\hline $\mathbf{7 5} \%$ & 6.92 & 7.67 & 7.92 & 7.75 & 7.56 \\
\hline $\mathbf{1 0 0} \%$ & 7.08 & 7.50 & 7.67 & 7.50 & 7.44 \\
\hline Mean & 6.75 & 7.19 & 7.42 & 7.28 & \\
\hline & RDN & & CUS & & RDN $\times$ CUS \\
\hline S.E. \pm & 0.101 & & 0.117 & & 0.203 \\
\hline CD at 5\% & 0.298 & & 0.344 & & NS \\
\hline
\end{tabular}


c) Leaf area at $30 \mathrm{DAS}$

\begin{tabular}{|c|c|c|c|c|c|}
\hline CUS & \multicolumn{3}{|c|}{ Leaf area $\left(\mathbf{c m}^{2}\right)$} & Mean \\
\hline RDN & $\mathbf{0 \%}$ & $\mathbf{5 \%}$ & $\mathbf{1 0} \%$ & $\mathbf{1 5} \%$ & \\
\hline $\mathbf{0 \%}$ & 166.50 & 168.96 & 175.75 & 172.51 & 170.93 \\
\hline $\mathbf{7 5} \%$ & 176.80 & 207.11 & 226.32 & 208.15 & 204.59 \\
\hline $\mathbf{1 0 0} \%$ & 177.65 & 207.40 & 218.63 & 208.88 & 203.14 \\
\hline Mean & 173.65 & 194.49 & 206.90 & 196.51 & \\
\hline
\end{tabular}

\begin{tabular}{|c|c|c|c|c|c|}
\hline & RDN & & CUS & & RDN $\times$ CUS \\
\hline S.E. \pm & 8.361 & & 9.654 & & 16.721 \\
\hline CD at $5 \%$ & 2.549 & & NS & & NS \\
\hline \multicolumn{6}{|l|}{ At 50 DAS } \\
\hline CUS & & \multicolumn{2}{|c|}{ Leaf area $\left(\mathrm{cm}^{2}\right)$} & \multirow[b]{2}{*}{$15 \%$} & Mean \\
\hline RDN & $0 \%$ & $5 \%$ & $10 \%$ & & \\
\hline $0 \%$ & 259.95 & 283.19 & 312.84 & 344.79 & 300.19 \\
\hline $75 \%$ & 267.87 & 324.95 & 446.59 & 393.62 & 358.26 \\
\hline $100 \%$ & 273.37 & 316.49 & 338.23 & 328.14 & 314.06 \\
\hline \multirow[t]{2}{*}{ Mean } & 267.06 & 308.21 & 365.89 & 355.52 & \\
\hline & RDN & & CUS & & RDN $\times$ CUS \\
\hline S.E. \pm & 12.323 & & 14.229 & & 24.646 \\
\hline CD at $5 \%$ & 36.182 & & 41.779 & & NS \\
\hline \multicolumn{6}{|l|}{ At 70 DAS } \\
\hline CUS & & \multicolumn{2}{|c|}{ Leaf area $\left(\mathrm{cm}^{2}\right)$} & & \multirow[t]{2}{*}{ Mean } \\
\hline RDN & $0 \%$ & $5 \%$ & $10 \%$ & $15 \%$ & \\
\hline $0 \%$ & 272.71 & 295.17 & 339.66 & 384.31 & 322.96 \\
\hline $75 \%$ & 389.42 & 469.79 & 556.11 & 515.59 & 482.73 \\
\hline $100 \%$ & 437.94 & 437.29 & 524.75 & 507.73 & 476.93 \\
\hline \multirow[t]{2}{*}{ Mean } & 366.69 & 400.75 & 473.51 & 469.21 & \\
\hline & RDN & & CUS & & RDN $\times$ CUS \\
\hline S.E. \pm & 12.819 & & 14.802 & & 25.638 \\
\hline CD at $5 \%$ & 37.638 & & 43.461 & & NS \\
\hline
\end{tabular}


Table.4 Effect of $\mathrm{N}$ fertilizers and foliar sprays of cattle urine on green fodder yield of maize (fodder) grown on inceptisol

\begin{tabular}{|c|c|c|c|c|c|}
\hline \multirow{2}{*}{ RDN } & \multicolumn{4}{|c|}{ Green fodder yield $\left(\mathrm{g} \mathrm{pot}^{-1}\right)$} & \multirow[t]{2}{*}{ Mean } \\
\hline & $0 \%$ & $5 \%$ & $10 \%$ & $15 \%$ & \\
\hline 0\% & 432.67 & 514.00 & 576.00 & 525.33 & 512.00 \\
\hline $75 \%$ & 889.33 & 959.00 & 1061.33 & 977.33 & 971.75 \\
\hline $100 \%$ & 914.67 & 944.00 & 1030.00 & 962.67 & 962.83 \\
\hline \multirow[t]{2}{*}{ Mean } & 745.56 & 805.67 & 889.11 & 821.78 & \\
\hline & \multicolumn{2}{|c|}{ RDN } & \multicolumn{2}{|c|}{ CUS } & $\mathbf{R D N} \times \mathbf{C U S}$ \\
\hline S.E. \pm & \multicolumn{2}{|c|}{18.310} & \multicolumn{2}{|c|}{21.142} & 36.620 \\
\hline CD at $5 \%$ & \multicolumn{2}{|c|}{53.761} & \multicolumn{2}{|c|}{62.078} & NS \\
\hline
\end{tabular}

Table.5 Effect $\mathrm{N}$ fertilizers and foliar sprays of cattle urine on nitrogen, phosphorus and potassium uptake by maize (fodder) in Inceptisol

\begin{tabular}{|c|c|c|c|c|c|}
\hline \multirow{2}{*}{ RDN } & \multicolumn{4}{|c|}{ Nitrogen uptake $N\left(\mathrm{~g} \mathrm{pot}^{-1}\right)$} & \multirow[t]{2}{*}{ Mean } \\
\hline & $0 \%$ & $5 \%$ & $10 \%$ & $15 \%$ & \\
\hline $0 \%$ & 1.15 & 1.15 & 1.30 & 1.47 & 1.27 \\
\hline $75 \%$ & 2.33 & 2.86 & 3.08 & 3.14 & 2.85 \\
\hline $100 \%$ & 2.67 & 2.93 & 3.70 & 4.80 & 3.54 \\
\hline Mean & 2.05 & 2.31 & 2.69 & 3.15 & \\
\hline & RDN & & CUS & & RDN $\times$ CUS \\
\hline S.E. \pm & 1.155 & & 0.179 & & 0.310 \\
\hline $\begin{array}{c}\text { CD at } \\
5 \%\end{array}$ & 0.455 & & 0.526 & & NS \\
\hline
\end{tabular}

\begin{tabular}{|c|c|c|c|c|c|}
\hline CUS & \multicolumn{4}{|c|}{ Phosphorus uptake $\mathbf{P}\left(\mathrm{g} \mathrm{pot}^{-1}\right)$} & \multirow[t]{2}{*}{ Mean } \\
\hline RDN & $0 \%$ & $5 \%$ & $10 \%$ & $15 \%$ & \\
\hline $0 \%$ & 0.35 & 0.40 & 0.57 & 0.49 & 0.45 \\
\hline $75 \%$ & 0.74 & 0.68 & 0.84 & 0.80 & 0.76 \\
\hline $100 \%$ & 0.72 & 0.84 & 1.07 & 0.97 & 0.90 \\
\hline \multirow[t]{2}{*}{ Mean } & 0.60 & 0.64 & 0.83 & 0.75 & \\
\hline & RDN & & CUS & & $\mathbf{R D N} \times \mathbf{C U S}$ \\
\hline S.E. \pm & 0.022 & & 0.025 & & 0.043 \\
\hline $\begin{array}{c}\text { CD at } \\
5 \%\end{array}$ & 0.064 & & 0.074 & & NS \\
\hline
\end{tabular}




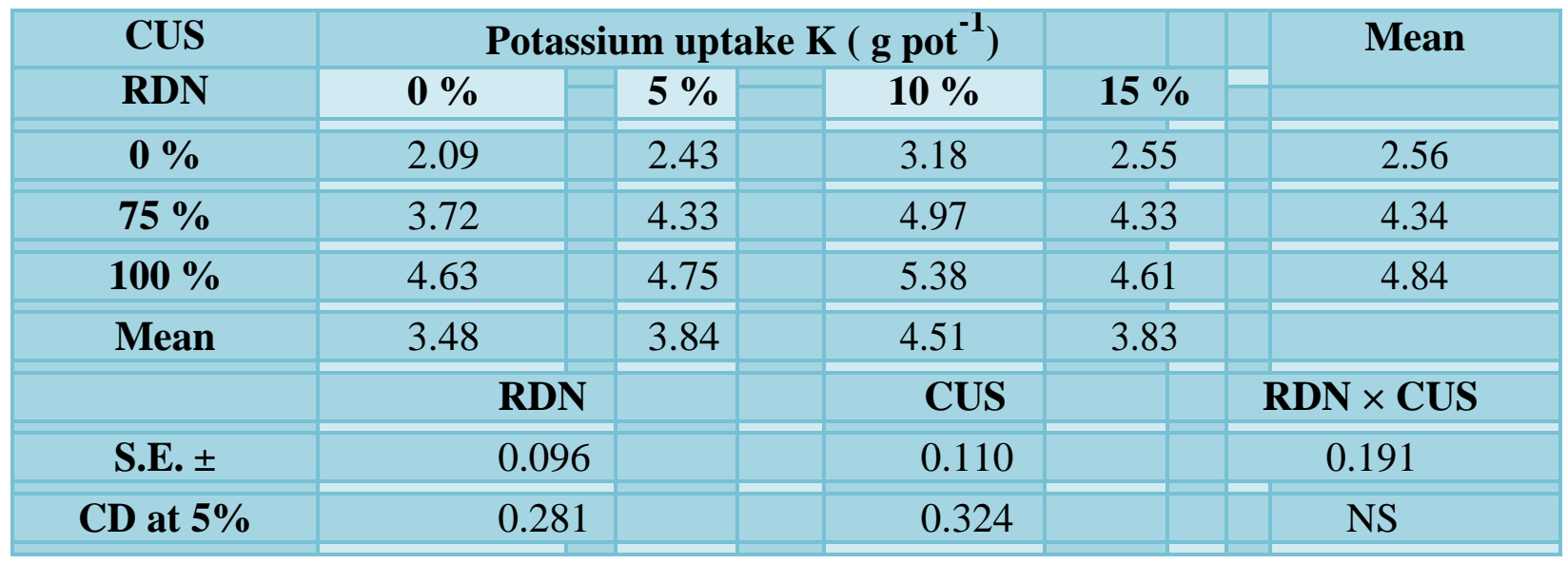

Application of $100 \% \mathrm{~N}$ through fertilizers recorded significantly higher $\mathrm{N}\left(3.54 \mathrm{~g} \mathrm{pot}^{-1}\right)$, $\mathrm{P}\left(0.90 \mathrm{~g} \mathrm{pot}^{-1}\right)$ and $\mathrm{K}\left(4.84 \mathrm{~g} \mathrm{pot}^{-1}\right)$ uptake by fodder maize this was followed by $75 \% \mathrm{~N}$ through fertilizers for $\mathrm{N}\left(2.85 \mathrm{~g} \mathrm{pot}^{-1}\right), \mathrm{P}(0.76$ $\left.\mathrm{g} \mathrm{pot}^{-1}\right)$ and $\mathrm{K}\left(4.34 \mathrm{~g} \mathrm{pot}^{-1}\right)$ uptake.

Foliar sprays of $15 \%$ CUS recorded significantly higher $\mathrm{N}$ (3.15 $\left.\mathrm{g} \mathrm{pot}^{-1}\right)$ uptake by fodder maize which was closely followed by $10 \%$ CUS (2.69 $\mathrm{g} \mathrm{pot}^{-1}$ ). Higher P uptake by fodder maize was observed with $10 \%$ CUS $\left(0.83 \mathrm{~g} \mathrm{pot}^{-1}\right)$ which was followed by $15 \%$ CUS $\left(0.75 \mathrm{~g} \mathrm{pot}^{-1}\right)$ however $10 \%$ cattle urine foliar sprays recorded significantly higher $\mathrm{K}$ (4.51 $\mathrm{g} \mathrm{pot}^{-1}$ ) uptake by fodder maize than rest of treatment.

Combine application of $\mathrm{N}$ fertilizers along with cattle urine foliar sprays recorded nonsignificant results for $\mathrm{N}, \mathrm{P}$ and $\mathrm{K}$ uptake. However numerically higher $\mathrm{N}$ uptake $(4.80 \mathrm{~g}$ $\left.\operatorname{pot}^{-1}\right)$ and $\mathrm{P}$ (1.07 $\left.\mathrm{g} \mathrm{pot}^{-1}\right)$ was recorded with $100 \% \mathrm{~N}+10 \%$ CUS but $100 \% \mathrm{~N}$ through fertilizers along with $10 \%$ CUS recorded higher K uptake by fodder maize (5.38 $\mathrm{g}$ pot $\left.{ }^{1}\right)$. Chute et al., (2017) reported similar effect of cow urine @ $4 \%$ and NAA @ 50 ppm reported higher chlorophyll, N, P, and K content in leaf of linseed, further Ledgard et al., (1982) reported that urine increased the $\mathrm{N}$ concentration of grass and increased the potassium concentration of grass and clover. Highest value of N, P and K uptake and its content in mustard recorded with combine application of $100 \%$ recommended dose of fertilizer with $12001 \mathrm{ha}^{-1}$ cow urine as basal and foliar spray of $50 \%$ urine. (Swayamprabha, et al., 2018). Singh, et al., (2014) also concluded that application of nitrogen @90 kg ha ${ }^{-1}$ with 60 kg ha ${ }^{-1}$ potassium and phosphorus + cow urine (T4) was found to be the best treatment regarding growth, yield and nitrogen content of paddy. These results are in close conformity Rahman, et al., (2008) similarly studied that application of cattle slurry@12 kg 10m² plot recorded significantly higher maize nutrient uptake Further they concluded that application of cattle slurry @10 kg $10 \mathrm{~m}^{2}$ plot $^{-1}$ (45 MT ha $\left.{ }^{1}\right)$ or $12 \mathrm{~kg} 10 \mathrm{~m}^{2} \operatorname{plot}^{-1}$ (44 MT ha ${ }^{-1}$ ) recorded statistically on par results for biomass yield of maize fodder. Nwite, J. N. (2015) results concluded that higher total nitrogen was obtained under human and cattle urine treatments relative to goat urine treated pots.

\section{References}

Bhadauria, H (2012) "Cow urine- a magical therapy. Vishwa Ayurveda Parishad International Journal of Cow Science. Vol. 1, pp. 32-36, 2002. 
Choudhary, S., Kushwaha, M., Seema, Singh Preeti, Sodani, R and Sunil Kumar (2017)

Cow urine: A boon for sustainable agriculture. International Journal of Current Microbiology and Applied Scienc 6, 1824-1829.

Chute, K. H., Deotale, R. D., Jadhav, G. N., Meshram, S. D. (2017) Influence of cow urine and NAA on chemical, biochemical and yield contributing parameters and yield of linseed. Bull. Env.Pharmacol. Life Science 6, 425430

Devkumar N. Sharma, S., Rao G.G.E. and Imran Khan (2014) Studies on soil fertility, cow urine and panchagavya levels on growth and yield of maize. In the processding $\mathrm{s}$ of the $4^{\text {th }}$ ISOFAR Scientific Conference. "Building Organic Bridges" at Organic World Congress 2014 13-15 Octomber held at Istanbul, Turkey.

Iqbal, A., Iqbal, M. A., Raza, A., Akbar, N., Abbas, N. and Khan, H. Z. (2014) Integrated

Nitrogen Management Studies in Forage Maize. American-Eurasian Journal Agriculture and Environment Science 14, 744-747.

Knudsen, D., Peterson, G.A. and Pratt, P.F. 1982. In Methods of Soil Analysis Part II Chemical and microbiological properties. Am. Soc. of Agron, Inc., Madison, Wisconsin,USA

Ledgard, S. F., Sheath, G. W., Gillingham, A. G. (1982) Influence of some soil andpasture components on the growth of hill country pastures L. Winter and spring production. New Zealand Journal of Experimental Agriculture 10, 239244.

Masti S.K., Pawar, A.D. and Roy D.S. (2003) Effect of liquid organic manures on growth characters of maize (Zea mays L.). Indian Journal of Agricultural
Science. 23 (5): 123-128

Meena R.P. and Bheemavati B.S. (2009) Moisture use functions and yield of rainfed maize as influenced by indigenous technologies. Asian Agricultural History 13 (2): 155-158.

National Collateral Management Services Limited (2017): NCoMM Special report. www.ncml.com

Nelson, D.W. and Somner, L. E. (1982) Total carbon, and organic matter. In A.L. page (ed) methods of Analysis Part II. Agronomy Am. method for multi element tissue analysis. Communications Soil Science Plant Analysis 425-436.

Nwite, J. N. (2015) Effect of different urine sources on soil chemical properties and maize yield in Abakaliki, Southeastern Nigeria. International Journal of Advance Agriculture Research 3, 31-36.

Olsen, S. R., Col C.V., Watanabe, F.S. and Dean, L.A.1954. Estimation of available phosphorous in soils by estimation with $\mathrm{NaHCO}_{3}$. USDA Cir. 939 (C.A. Black 1965) Am. Soc. Inc. Mad. W.B.USA: 1035.

Pande,S., Naik, M.R. and Naidu, S.M. (2015) Effect of different sources of organic manures on sween corn (Zea mays Saccharata). Environment and Ecology. 33(2A):810-813.

Patil, S. V., Halikatti, S. I., Hiremath, S. M., Babalad,H. B., Sreenivasa,M. N., Hebsur,

N. S., and Somanagouda, G. (2012) Effect of organics on growth and yield of chickpea in Vertisol. Karnataka Journal of Agricultural Science 25, (326-331).

Pradhan,S.,Bohra, J.S. Bahadur, S., Singh, M.K. and Ram, L. (2016) Effect of fertility levels and cow urine application on the growth and uptake of nutrients of Indian Mustard (Brassica juncea L.) Research on Crops, 17 (4):77-84

Rahman, S. M. E. Islam, M. A.,Rahman, M. 
M.and Deog-Hwan (2008) Effect of cattle slurry on growth, biomass, yield and chemical composition of maize fodder. Asian-Australian Journal of Animal Science, 21, 1592-1598.

Ravi kumar, H. S., Janakiraman, N., Sheshadri, T., Venkate gowda, J., and Vijaymahantesh, (2012) Integrated organic nutrient supply systems on growth and yield of groundnut (Arachis hypogaea L.) Department of agronomy, university agricultural sciences, GKVK, Bengaluru 560065. India environment \& ecology 30, 118-121.

Sadhukhan, R. Bohra, J.S. and Choudhury, S. (2018) Effect of fertility levels and cow urine foliar spray on growth and yield of wheat. .International Journal of Current Microbiology and Applied Sciences 7, 907-912.

Sathyamoorthi K.(1997) Response of green gram (Vigna radiate $\mathrm{L}$ ) to increase plant density and foliar fertilization through soil and foliage. Ph.D. thesis submitted to Tamil Nadu Agricultural University, Coimbatore.
Sharma, R., Shah, S. C., Adhikari, K.R., Shah, P. and Shrestha, J. (2016) Effect of cattle urine and FYM on yield of broccoli and soil properties. Journal of AgriSearch 3, 157- 160

Singh, M. K., Singh, R. P. and Rai, S. (2014) Effect of nitrogen levels and cow Urine on soil $\mathrm{N}$ status, growth and yield of paddy (Oryza sativa L.). Environment and Ecology 32, 1277-1281.

Subbia, B. V. and Asijia, G. L. 1956. A rapid procedure for the estimation of available nitrogen in soils. Curr. Sci.25, 259-260.

Swayamprabha Pradhan, S., Verma, S., Kumari, S. and Yashwant Singh. (2018) Bioefficacy of cow urine on crop production: A review. International Journal of Chemical Studies 6, 298-301.

Tanko, U., Musa, and Hassan, U. T. (2011) Leaf area determination for maize ( $\mathrm{Zea}$ mays L.). Journal of Biology, Agriculture and Healthcare, 4, 130-111.

Verma, S.S.(1989) Effect of nitrogen and seed rate and method of sowing on forage oat. Forage Research 15(1):29.

\section{How to cite this article:}

Jadhav. A. B., A. M. Marbhal, G. D. Patil, A. C. Jadhav and Pachpute. S. T. 2020. Effect of Nitrogen and Foliar Sprays of Cattle Urine on Growth, Yield and Nutrient Uptake by Maize (Fodder) Grown on Inceptisol. Int.J.Curr.Microbiol.App.Sci. 9(05): 155-166. doi: https://doi.org/10.20546/ijcmas.2020.905.017 